\title{
FEDERAL INTERFERENCE WITH GHECKS AND BALANCES IN STATE GOVERNMENT: A CONSTITUTIONAL LIMIT ON THE SPENDING POWER
}

The contribution of federal grant money to state budgets has so increased in amount and changed in form that state legislatures increasingly find themselves with little real control over substantial portions of state expenditures. By 1976, federal aid to many states constituted over twenty per cent of the state budget; ${ }^{1}$ moreover, a significant amount of this aid is now in the form of "block grants" administered by state agencies with great discretion over their utilization. ${ }^{2}$ The federal statutes give planning responsibilities almost exclusively to the state agencies and assign almost no role to the state legislatures in the use of block grants. ${ }^{3}$ As a result, legislators must increasingly submit not to Congress's priorities but to those set by state bureaucrats and specialists usually representing the executive branch of state government.

1 U.S. ADVISORY COMMISSION ON INTERGOVERNMENTAX RELATIONS, INFORMAtion Bull. No. 76-4: State Legislatures and Federal Grants 1 (1976) [hereinafter cited as ACIR Buxr.]; see Shapp v. Sloan, 480 Pa. 449, 459, 468, 391 A.2d 595, 600, 604 (1978), appeal dismissed sub nom. Thornburgh v. Casey, 440 U.S. 942 (1979).

2 From 1968 to 1976, block grants increased from less than 3\% of federal aid to approximately 12\%. ACIR BuL.L., supra note 1 , at 2 . In contrast, categorical grants, which still account for a large majority of federal grants, normally have elaborate conditions attached regulating precisely how the funds may be spent.

The exact number of block-grant programs "depends on who does the counting." Dam, The American Fiscal Constitution, 44 U. Crr. L. Rev. 271, 315 (1977). There are at least five block-grant programs: the Comprehensive Employment and Training Act, 29 U.S.C. $\$ 801-992$ (1976); the Partnerships for Health Act, 42 U.S.C. $\$ 246$ (1976); the Social Services Amendments of 1974, id. $\$ \S 1397-1397$; the Omnibus Crime Control and Safe Streets Act, id. $\$ \$ 3701-3796 \mathrm{c}$; the Community Block Development Grant portion of the Housing Community Development Act of 1974 , id. $\$ \$ 5301-5317$. See U.S. Advisory CommISsron on InTERGovernamental Relatrons, Block Grants: A Roundtable Discussion, No. A-51 at ii [hereinafter cited as RouNDTABLE]; Dam, supra, at 315.

3 For instance, under the Omnibus Crime Control and Safe Streets Act, 42 U.S.C. $\$ \$ 3701-3796 \mathrm{c}$ (1976) ("Crime Control Act"), the legislature's only role is an advisory review of the state administrative agency's comprehensive plan. See id. \$ 3726; text accompanying notes 17-28 infra.

The Crime Control Act is exceptional for block-grant programs because of its explicit definition of executive and legislative responsibility. More often, Congress requires that a grant program be administered by a state agency without specifying in which branch of government the agency is to be located. E.g., Elementary and Secondary Education Act, 20 U.S.C. \$ $24 \mathrm{lg}$ (1976); Partnerships for Health Act, 42 U.S.C. $\$ 246$ (a) (2) \& (d)(2) (1976), legislative appropriation or participation is not prohibited by other statutes; rather, it is simply not mentioned. 
In the legislatures' view, their resulting loss of control "is at the heart of the practical exercise of power at the state level. If we cannot control the purse strings, then we are nothing." 4 To regain control of the purse strings, at least two state legislatures have passed "reappropriation acts" giving themselves express power to appropriate, project by project, all federal funds flowing to the state government. 5 Where the federal laws creating the grants assign no such role to the legislatures, the state and federal laws may conflict, and the state law would thus be held invalid under the supremacy clause ${ }^{6}$ unless the federal law were found to be unconstitutional.

This Comment examines one possible limit to constitutionality ${ }^{7}$-whether a federal law specifying that the executive, rather than legislative, branch of a state government receive and spend federal grant money intrudes so substantially on state sovereignty ${ }^{s}$ that it violates the tenth amendment. ${ }^{9}$ This issue was present but

4 ACIR BurL., supra note 1 , at 14 (remarks of Harold Schreier to the National Conference of State Legislatures). Mr. Schreier also noted that there is a continuing "struggle to keep the Madison check and balance system of three coequal branches of govermment, and the legislatures of this country are losing." Id.

5 PA. Stat. ANn. tit. 72, $\$ 4611-4617$ (Purdon Supp. 1979-80); S.D. CoMp. Laws ANN. §4-8B-10 (Supp. 1978). Another one-third of the states normally include many federal grants in their appropriations and thus could, at least theoretically, exert control over how federal funds are spent within the state. See ACIR Boux., supra note 1, at 13. This Bulletin urges all states to adopt "reappropriation" statutes like those of Pennsylvania and South Dakota. Id.

6 U.S. Const. art. VI, cl. 2.

7 Other possible limits are provided by the Bill of Rights. See generally, e.g., O'Neil, Unconstitutional Conditions: Welfare Benefits With Strings Attached, 54 CALIF. L. REv. 443 (1966); Wilcox, Invasions of the First Amendment Through Conditioned Public Spending, 41 CoRNan.L L.Q. 12 (1955); Note, Unconstitutional Conditions, 73 Harv. L. Rev. 1595 (1960).

8 See Shapp v. Sloan, 480 Pa. 449, 478, 391 A.2d 595, 609 (1978), appeal dismissed sub nom. Thornburgh v. Casey, 440 U.S. 942 (1979) (dissent).

$9 \mathrm{~A}$ finding of unconstitutionality of intrusions on state sovereignty is often grounded in the tenth amendment. E.g., National League of Cities v. Usery, 426 U.S. 833, 842-43 (1976) ("NLC"). Some commentators, however, would base it on a principle "deeper" than that articulated in the tenth amendment. E.g., Wechsler, The Political Safeguards of Federalism: The Rolle of the States in the Composition and Selection of the National Government, 54 Colum. L. Rev. 543, 544-45 (1954). Although this Comment refers to violations of the "tenth amendment," it should be understood as referring to constitutional guarantees of state sovereignty, from wherever derived.

For other commentary on post-NLC tenth-amendment limitations on congressional spending power, see generally Stewart, Pyramids of Sacrifice? Problems of Federalism in Mandating State Implementation of National Environmental Policy, 86 Y ALE L.J. 1196 (1977); Comment, Toward New Safeguards on Conditional Spending: Implications of National League of Cities v. Usery, 26 AM. U. L. REv. 726 (1977) [hereinafter cited as New Safeguards]; Note, Municipal Bankruptcy, the Tenth Amendment and the New Federalism, 89 Hanv. L. Rev. 1871 (1976) [hereinafter cited as Municipal Bankruptcy]. See also Barber, National League of 
not fully explored when Pennsylvania's reappropriation act, Act $117,{ }^{10}$ was challenged by the governor in Shapp v. Sloan. ${ }^{11}$ With Act 117, the Pennsylvania legislature refused to appropriate that part of a block grant from the Law Enforcement Assistance Administration (LEAA) that would have funded a special prosecutor within the executive branch. Governor Shapp argued that the Omnibus Crime Control and Safe Streets Act (Crime Control Act), ${ }^{12}$ which created LEAA, explicitly bars legislative control of federal monies received under it. ${ }^{13}$ The state supreme court, however, upheld the statute. Although the United States Supreme Court refused to hear an appeal, ${ }^{14}$ probably for procedural reasons, ${ }^{15}$ the apparent conflict between federal and state law remains. Thus, when a case arises in the proper procedural posture, this conflict will require the Court to face this constitutional issue.

Because that particular controversy demonstrates well the important federal-state conflict that is the subject of this Comment, part I outlines the LEAA block-grant program and Act 117 and traces the Pennsylvania governor's challenge to Act 117 in Shapp v. Sloan. Part II(A) examines the constitutionality of Congress's vesting control of its grants in a particular branch of state government, especially in light of National League of Cities v. Usery ("NLC").16 Part II(B) concludes that under normal spending-power analysis, even after $N L C$, grant conditions that affect the structure of state government do not violate the tenth amendment. Part II(C), however, concludes that the peculiar interference with state sovereignty caused when state legislatures are all but excluded from the block-grant process creates an exception to the normal analysis and therefore violates the tenth amendment. Part III suggests that even if mandating executive control of block grants is constitutional, considerations of state sovereignty and federalism limit the relief a federal court can give to a state governor in disputes in which the legislature has blocked the executive from carrying out the terms of the federal grant.

Cities v. Usery: New Meaning for the Tenth Amendment?, 1976 SUP. CT. Rev. 161; Heldt, The Tenth Amendment Iceberg, 30 Hastings L.J. 1763 (1979); Ripple \& Kenyon, State Sovereignty-A Polished But Slippery Crown, 54 Notre DAME L. 745 (1979).

10 Pa. Stat. Ann. tit. 72, $\$ \$ 4611-4617$ (Purdon Supp. 1979-80).

11480 Pa. 449, 391 A.2d 595 (1978), appeal dismissed sub nom. Thornburgh

v. Casey, 440 U.S. 942 (1979).

1242 U.S.C. $\$ \$ 3701-3796 \mathrm{c}$ (1976).

13 Id. $\$ 3726$. See note 3 supra.

14 Thornburgh v. Casey, 440 U.S. 942 (1979).

15 See text accompanying notes 52-55 infra.

16426 U.S. 833 (1976). 


\section{A Case History}

\section{A. The Statutory Conflict: The Legislature's Role under LEAA and Act 117}

The Crime Control Act directs that LEAA block grants be administered by the state's executive branch. ${ }^{17}$ Under the Act, an agency "subject to the jurisdiction of the [state's] chief executive" 18 submits an annual comprehensive plan to the LEAA ${ }^{19}$ and receives and disburses funds according to the plan. ${ }^{20}$

The legislature, in contrast, has almost no role. Originally, the legislature was not even mentioned in the Crime Control Act, but the Act was amended in 1976 to give the legislature an optional advisory review of the agency's comprehensive plan. ${ }^{21}$ Committee reports, ${ }^{22}$ Hloor debate, ${ }^{23}$ and defeat of measures designed to give the legislature control of LEAA funds ${ }^{24}$ underscore the limited, nonbinding role that Congress intended for the legislatures. The Senate Report said:

$[\mathrm{P}]$ lacing the State planning agency under the jurisdiction of the State legislature rather than the chief executive

1742 U.S.C. $\$ 3723(\mathrm{a})(1)$ (1976). See id. $\$ \$ 3732(\mathrm{a}), 3733(\mathrm{a})(1)$.

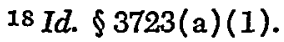

19 Id. $\$ \$ 3723(\mathrm{~b})(1), 3732(\mathrm{a}), 3733(\mathrm{a})$.

20 The LEAA "shall make grants under this chapter to a State planning agency." Id. $\$ 3733$ (a) (emphasis added).

21 The amended provision reads:

At the request of the State legislature ... the comprehensive statewide plan shall be submitted to the legislature for an advisory review prior to its submission to the Administration by the chief executive of the State. In this review the general goals, priorities, and policies that comprise [sic] the basis of that plan, including possible conflicts with State statutes or prior legislative Acts, shall be considered. If the legislature . . . has not reviewed the plan forty-five days after receipt, such plans [sic] shall then be deemed reviewed.

Id. $\$ 3726$.

22 S. Rep. No. 94-847, 94th Cong., 2d Sess. 16-17, reprinted in [1976] U.S. Code Cong. \& AD. News 5374, 5381-82; H.R. REP. No. 94-1155, 94th Cong., 2d Sess. 7, 13, 20 ("This section does not give approval or disapproval power to State legislatures over the plans.").

23 Senator Dirksen noted:

We are never going to do a job in this field until we have a captain at the top, in the form of the Governor, and those he appoints, to coordinate matters for a state ....

.. [I]f we are going to do a job, it has to be unfragmented, and the only way it can be done is to make certain that this goes from the top down and that it goes through the hands of the Governors of the States.

114 Cong. REc. 14753 (1968).

24 See S. Rep. No. 94-847, 94th Cong., $2 \mathrm{~d}$ Sess. 16, reprinted in [1976] U.S. Code Cong. \& AD. News 5374, 5381; H.R. Rep. No. 94-1155, 94th Cong., $2 \mathrm{~d}$ Sess. 7. 
would be inappropriate. It would be inconsistent with the centralized and coordinated statewide planning that is one of the key elements of the LEAA program and render close supervision more difficult. Such a structuring of the program would also create a greater danger of politicization of the LEAA effort. ${ }^{25}$

Congress had not yet provided for this advisory legislative review when Pennsylvania's Act 117 was passed; ${ }^{26}$ thus, other than through control of matching funds, ${ }^{27}$ state legislatures had no role in the administration of LEAA grants. ${ }^{28}$ Indeed, other oversight tools, such as line-by-line matching, were ineffective, ${ }^{29}$ and the Pennsyl-

25 S. Rep. No. 94-847, 94th Cong., 2d Sess. 16, reprinted in [1976] U.S. CodE Cong. \& AD. News 5374, 5381.

26 Act 117 was passed over the governor's veto on June 29, $1976.1976 \mathrm{~Pa}$. Laws 469. Advisory review was enacted on October 15, 1976 by Pub. L. No. $94-503, \S 108,90$ Stat. 2411 (1976).

27 Almost all LEAA federal grants require some state matching funds. See, e.g., 42 U.S.C. $\$ \$ 3724,3736(\mathrm{a}), 3746(\mathrm{e}), 3750 \mathrm{~d}(\mathrm{a})$ (1976). This match requirement does not, however, enable the state legislature to set priorities within the comprehensive LEAA plan or delete specific projects. See note 29 infra.

28 A legislature admittedly could hold oversight hearings and conduct investigations into state LEAA programs. S. REP. No. 94-847, 94th Cong., 2d Sess. 16, reprinted in [1976] U.S. CODE CoNG. \& AD. NEws 5374, 5382. The legislature may also be able to block specific elements of a state agency's plan before it is submitted to LEAA by passing substantive, not appropriations, measures. "Because the LEAA will not approve a state plan that is inconsistent with state law, the legislature also can require the elimination from a proposed plan of a specific project by enacting a statute prohibiting the implementation of the project." Brief for the United States as Amicus Curiae, at 16, Thomburgh v, Casey, 440 U.S. 942 (1979) (footnote omitted) [hereinafter cited as Solicitor's Brief].

While this technique may be viable now that the state legislature can review a state agency's plan before its submission to LEAA, the legislature has no practical means of influencing the application of LEAA funds once the advisory review is done. For a discussion of whether this substantive review is an adequate substitute for the appropriation power, see text accompanying notes 123-27 infra. Indeed, it is unclear that this veto power over specific projects was contemplated by Congress, which referred to the nonbinding nature of the advisory review and its focus on "general goals, priorities, and policies." See notes 21 \& 22 supra.

29 Because of "aggregate" and "overmatch" funding concepts, a state agency can obtain full funding for a project despite the state legislature's refusal to supply matching funds for that project. The Crime Control Act does not require that the state provide matching funds for each project but only that the "aggregate" state funding for the total LEAA program match the total federal funding (at a 9:1 ratio). See 42 U.S.C. $\$ 3731$ (c) (1976); H.R. REP. No. 93-249, 93d Cong., Ist Sess. 6, reprinted in [1973] U.S. CoDE CoNG. \& AD. NEws 1729, 1732. Furthermore, the state agency may take federal funds that are unnecessary to one project (because the legislature appropriated more than is required) and apply that "overmatch" to a project that the legislature refused to fund:

The matching provisions may be properly interpreted to permit overmatch in one program to apply to other programs within a functional category. ... This interpretation should be helpful to the States that are going to have problems getting matching funds from their legislatures, since LEAA will permit them to seek 100 percent funding by the legislatures of programs that they can sell to the legislature and apply the overmatch to other programs that are not as attractive to the legislature. 
vania General Assembly moved to take control of LEAA grants ${ }^{30}$ by passing Act 117.31 Through this statute the legislature, which felt that the increased use of federal funds had "undermined... [its] control of state spending," intended to reassert full control over the state budget. ${ }^{32}$

Act 117 requires that all federal funds be pooled with the state's general revenues ${ }^{33}$ and that no general revenues be spent without specific legislative appropriation, even if the funds were received from the federal government as matching funds for specific projects. $^{34}$ The funds are then allocated annually by the General Assembly. 35

The General Assembly then immediately provoked a crisis by refusing to allocate funds granted by the LEAA for the controversial Office of the Special Prosecutor. ${ }^{36}$ Warning that Pennsylvania could

LEAA Legal Op. No. 71-7, at 45 (1971), reprinted in Law Enforcement Assistance Administration: Hearings Before the Subcomm. on Crime of the House Comm. on the Judiciary, 94th Cong., 2d Sess. 1984, 1985; see LEAA Legal Op. No. 74-56, at 68 (1974); LEAA Legal Op. No. 74-60, at 76 (1974); Record at 402a-03a, Shapp v. Sloan, $480 \mathrm{~Pa}$. 449, 391 A.2d 595 (1978). Overmatch may also be used between fiscal years. LEAA Legal Op. No. 74-56, at 68-69.

Thus, subprogram or "line" appropriations of matching funds become, in effect, irrelevant, as the Pennsylvania General Assembly discovered when it first tried to scuttle the controversial Office of the Special Prosecutor by refusing to appropriate matching funds for that project. The governor's state-planning agency responded by obtaining permission from LEAA to employ the overmatch technique and thereby support the special prosecutor exclusively on federal funds. Record at 403a-07a. The overmatch concept, as thus applied, survived two court tests in Gwinn v. Kane, $465 \mathrm{~Pa} .269,285,348$ A.2d 900, 908 (1975), and Myers v. Kane, $23 \mathrm{~Pa}$. Commw. Ct. 213, 217, 350 A.2d 909, 911 (1976), persuading the legislature that, if it wanted to screen projects or conform LEAA expenditures to its own priorities, it would have to appropriate the federal grants itself.

30 In fiscal year 1976, LEAA block grants to Pennsylvania were greater than $\$ 40,000,000$. See EIGHTH ANNUAL REPORT OF LEAA 95 (1976).

31 PA. Stat. ANN. tit. 72, $\$ 4611-4617$ (Purdon Supp. 1979-80).

32 ACIR BuLc., supra note 1, at 2 (remarks of Michael Hershock, Exec. Dir.,

Pa. House Approp. Comm.). Hershock said that the increased federal presence

had occurred without a concurrent change in the way the General Assem-

bly reviews the state's budget. The additional spending power and the additional flexibility which resulted from this growth in federal funds had been used almost exclusively to strengthen the hand of the [state] execuId. tive branch in the budgetary process.

33 Pa. Stat. ANN. tit. 72, $\$ 4615$ (Purdon Supp. 1979-80).

34 Id. $\$ \$ 4613-4614$.

35 The General Assembly passes annual "Federal Augmentation Appropriation Acts." E.g., Act No. 12-A, 1977 Pa. Laws 452; Act No. 17-A, 1976 Pa. Laws 1383.

36 See Shapp v. Sloan, 480 Pa. 449, 482-83, 391 A.2d 595, 611-12 (1978), appeal dismissed sub nom. Thomburgh v. Casey, 440 U.S. 942 (1979) (dissent); Phila. Evening Bull., June 29, 1976, at 1, col. 2; Phila. Inquirer, July 1, 1976, at 1, col. 5 ; id., June $30,1976, \S \mathrm{B}$, at 1 , col. 6 .

The General Assembly had previously tried to terminate the special prosecutor's office by refusing to provide state matching funds. See note 29 supra. 
as a result lose all of its funds under the Crime Control Act, the LEAA contended that the General Assembly's actions contradicted federal law:

The Pennsylvania Acts . . appropriate LEAA monies in a manner inconsistent with the State's comprehensive ... plans and are in derogation of the Governor's responsibility to develop and implement State comprehensive plans pursuant to the Crime Control Act. The refusal of the State Treasurer to honor previously approved fund requisitions contravenes the act and the LEAA grant conditions upon which the State of Pennsylvania received its LEAA funding. ${ }^{37}$

Governor Shapp then went to court to force appropriation of funds for the special prosecutor. ${ }^{38}$

\section{B. The Governor's Challenge-Shapp v. Sloan}

In Shapp v. Sloan, ${ }^{39}$ a plurality ${ }^{40}$ of the Pennsylvania Supreme Court upheld the General Assembly's reappropriation of all federal grants. Before reaching this issue, the court had to decide that the state constitution permitted the state legislature to reappropriate federal grants. ${ }^{41}$ Indeed, in past disputes between state executives and legislatures, state judges had resolved the cases on state-law grounds, focusing on what constitutes "public funds." In short, superficial opinions, they uniformly held that "federal contributions are not the subject of the appropriation power of the legislature." 42

37 LEAA Legal Op. No. 77-5, at 309, 310 (1977).

38 See Shapp v. Sloan, 480 Pa. 449, 391 A.2d 595 (1978), appeal dismissed $s u b$ nom. Thomburgh v. Casey, 440 U.S. 942 (1979). The Governor stated:

I am directing the Attomey General to take immediate steps to invalidate [Act 117] . . . and to invalidate the entire act which $I$ now must reluctantly sign and to establish the principle that Federal funds go directly to the State or local government named in the Federal statute or regulation involved.

$1976 \mathrm{~Pa}$. Laws 1423 (remarks of Gov. Shapp, signing the Federal Augmentation Appropriation Act of 1976, Act No. 17-A, 1976 Pa. Laws 1383).

$39480 \mathrm{~Pa} .449,391$ A.2d 595 (1978), appeal dismissed sub nom. Thornburgh v. Casey, 440 U.S. 942 (1979).

40 Justice Manderino's opinion was joined by two other justices. Justice Pomeroy concurred in the result without opinion. Justice Roberts, joined by one other justice, filed a dissenting opinion. See id. at 476, 391 A.2d at 608 .

41 Id. at $463-68,391 \mathrm{~A} .2 \mathrm{~d}$ at $602-04$.

42 MacManus v. Love, 179 Colo. 218, 222, 499 P.2d 609, 610 (1972); see State ex rel. Sego v. Kirkpatrick, 86 N.M. 359, 370, 524 P.2d 975, 986 (1974); accord, Navajo Tribe v. Arizona Dep't of Administration, 111 Ariz. 279, 280-81, 528 P.2d 623, 624-25 (1974). 
The plurality of the Pennsylvania Supreme Court held that past interpretations of "public funds" were irrelevant because earlier courts "could not anticipate that ... federal funds would constitute a large portion of the budgets of most states." 43 The justices warned that growing federal aid coupled with exclusive gubernatorial control would "eliminate the need for a legislative branch of government," 44 violating the doctrine of separation of powers. Federal grants were therefore "public funds" and subject to legislative reappropriation under the Pennsylvania Constitution..$^{45}$

Thus embarking on a new trail, the Shapp plurality addressed the federal constitutional question and announced that it found no "clear and direct" conflict between state and federal law that would trigger the supremacy clause. ${ }^{46}$ It said:

Nothing in the federal legislation ... suggests that the ... principles [of separation of powers] by which programs wholly state funded are operated are inapplicable to programs for which federal funds are supplied. That the executive agency or official must use federal monies within the program for which they were intended, and must provide an accounting to show that they were so used, does not lead to the conclusion that the funds are under that official's control and outside the control of the legislature. ${ }^{47}$

In reaching this decision, the court gave inadequate attention to the words and legislative history of the Crime Control Act. Instead, it relied on recommendations of the Advisory Commission on Intergovernmental Relations (ACIR) ${ }^{48}$ in support of more legislative participation in grant programs. Because most other federal grant statutes were silent on the issue of state legislative participation, ${ }^{49}$ and because recent federal policy was geared towards giving

$43480 \mathrm{~Pa}$. at $466,391 \mathrm{~A} .2 \mathrm{~d}$ at 603.

44 Id. at $468,391 \mathrm{~A} .2 \mathrm{~d}$ at 604 .

45 PA. Const. art. III, $\$ 24$.

$46480 \mathrm{~Pa}$. at $472,391 \mathrm{~A} .2 \mathrm{~d}$ at 606.

47 Id. at $469,391 \mathrm{~A} .2 \mathrm{~d}$ at 604 .

48 Id. at 470-71, 391 A.2d at 605-06 (citing ACIR BuLL., supra note 1).

49 See note 3 supra. The subject is further clouded in that one-third of the states commonly appropriate federal grants, see note 5 supra, arguably with Congress's tacit consent. Indeed, even the dissenters in Shapp seemed unconvinced that gubernatorial control was mandated in every grant program. $480 \mathrm{~Pa}$. at 478 , 391 A.2d at 609 n.3. 
state governments more discretion over administration, the justices concluded that "it cannot . . . be considered an encroachment upon. federal supremacy that the legislature, rather than the executive, exercises the discretion granted the state government by the Congress." ${ }^{0} 0$

Although Shapp v. Sloan surely raises a crucial issue of federalism, the Supreme Court dismissed the appeal for want of a substantial federal question. ${ }^{61}$ The Solicitor General's brief, filed. at the Court's request, ${ }^{52}$ strongly suggests that the appeal was dismissed for procedural reasons rather than because the Court thought there were no substantial questions.

The Solicitor General pointed out that no matter how the substantive issues were decided, the Governor would not be entitled to declaratory relief: ${ }^{53}$

[I]t makes no difference whether the appellants [including the governor] are correct in their contention that the state appropriation acts are inconsistent with Title I [of the Crime Control Act]. If, as appellants maintain, Act No. 117 violates the conditions of eligibility for the federal grant, then Pennsylvania is not entitled to receive the federal funds whose availability is conditioned on compliance with the federal terms.... And if appellants are incorrect in their interpretation of Title $I$, the result is the same, because then federal law provides no impediment to the legislative decision to withhold funds from the Special Prosecutor's Office. ... [N]o declaration could have produced-or would in the future produce-the fiscal controls appellants seek. ${ }^{54}$

$50480 \mathrm{~Pa}$. at $470,391 \mathrm{~A} .2 \mathrm{~d}$ at 605 .

A sharp dissent was filed demonstrating the conflict between state and federal law. The dissenters concluded that the legislature could not "prevent the stateexecutive from using federal funds for the purpose for which they were granted to the state by Congress and the LEAA." Id. at 479, 391 A.2d at 609 .

51 Thomburgh v. Casey, 440 U.S. 942 (1979).

52439 U.S. 1043 (1978); see Solicitor's Brief, supra note 28, at 1.

53 The governor sought both declaratory relief and a permanent injunction requiring release of funds for the special prosecutor. The demise of the special prosecutor's office mooted the injunction request. Solicitor's Brief, supra note 28, at 14. In addition to the reasons cited in the text and the mootness of part of the case, the appeal presented another problem: the question on appeal may have been so broadly stated as to render the issue non-justiciable. Id. 9-12. But see id. 12-14.

54 Id. 18-19 (footnotes omitted). 
Although there was no substantial federal question, the Solicitor General agreed that the Court would have to decide a similar case if the procedural posture were different:

[T] he question of the consistency of a state reappropriation act with a federal grant statute properly could be raised by a state's challenge to a federal agency's refusal to make such a grant on the ground that the state act was inconsistent with the terms of the congressional offer of assistance. ${ }^{55}$

Thus, if the question were properly raised, and the Court found that the state and federal laws were inconsistent, it would then have to decide if the federal law unconstitutionally impinged on state sovereignty.

\section{The Constirutronal Analysis}

A. National League of Cities v. Usery

The broad rhetoric of National League of Cities $v$. Usery ("NLC") ${ }^{56}$ breathed new life into state sovereignty as a constitutional limit on Congress's powers. In $N L C$, the Court held that the minimum-wage and maximum-hour provisions of a federal law ${ }^{57}$ were unconstitutional as interferences "with traditional aspects of state sovereignty." 58 In attempting to set the wages and hours of employees of state governments, said the Court, Congress was using "its power in a fashion that would impair the States' 'ability to function effectively in a federal system." Because this "exercise ... operate[s] to directly displace the States' freedom to structure integral operations in areas of traditional governmental functions, ... [it is] not within the authority granted Congress by Art. I, $\S 8$, cl. 3." 59

$N L C$ leaves unclear exactly which state sovereignty interests are protected by the Constitution. ${ }^{60}$ When $N L C$ refers to "in-

55 Id. 19 n.17.

56426 U.S. 833 (1976).

57 Fair Labor Standards Act, 29 U.S.C. $\$ \$ 201-219$ (1976).

58426 U.S. at 849.

59 Id. 852 (citations omitted).

60 See, e.g., id. 880 (Brennan, J., dissenting); Field, The Eleventh Amendment and Other Sovereign Immunity Doctrines: Congressional Imposition of Suit Upon the States, 126 U. PA. L. REv. 1203, 1220-21 (1978); Michelman, States' Rights . and States" Roles: Permutations of "Sovereignty" in National League of Cities v. Usery, 86 YALE L.J. 1165, 1172 (1977); Tribe, Unraveling National League of 
tegral governmental functions" or undoubted "attributes of sovereignty," 61 it seems to contemplate an ill-defined category of services, such as sanitation and fire protection. ${ }^{62}$ Still, the language of $N L C$ is broad enough ${ }^{63}$ to have led many commentators to agree that Congress may not "insist that a state alter its basic governmental structure." ${ }_{44}$ Typical of this view is Professor Stewart's position that $N L C$ protects two aspects of state sovereignty: the liberty to determine which services to provide, and "the liberty to determine the structure of state and local governmental decisionmaking machinery and the concomitant ability to operate that machinery." "65 The interest in structural independence "is weightier because it is more basic and logically prior to" the interest in local services. ${ }^{66}$ There is, then, a strong argument that protection of a state's system of checks and balances from the sort of intrusion caused by block-grant programs is a more important interest.

Thus, $N L C$ suggests that if the Crime Control Act, by altering the existing relationship between the executive and legislative branches of state government, interferes with a state's liberty to structure and operate "decisionmaking machinery," then it might be unconstitutional. $^{\text {"T }}$ The LEAA grant programs of the Crime Control Act, however, unlike the legislation invalidated in NLC, are

Cities: The New Federalism and Affirmative Rights to Essential Government Services, 90 HARv. L. Rev. 1065, 1069, 1072-75 (1977); Municipal Bankruptcy, supra note 9, at 1881-82; Comment, Applying the Equal Pay Act to State and Local Governments: The Effect of National League of Cities v. Usery, 125 U. PA. L. REv. 665, 672-76 (1977) [hereinafter cited as Equal Pay Act].

61426 U.S. at 845.

62 See id. 851.

63 There is language in the Court's opinion that suggests a broader range of state sovereignty interests than mere management of public service. Justice Rehnquist cited Coyle v. Smith, 221 U.S. 559 (1911), which reserved to the state the right to choose the location of its capital, for the proposition that "there are attributes of sovereignty attaching to every state government which may not be impaired by Congress." Id. 845.

64 L. Trube, Amertcan Constixutional Law 302 (1978). See also G. GunTHer, Constitutional Law 125 (9th ed. 1975); Dam, supra note 2, at 293-94; Stewart, supra note 9, at 1231; Municipal Bankruptcy, supra note 9, at 1886-88.

65 Stewart, supra note 9, at 1231.

66 Id. 1232.

67 Although the Pennsylvania Supreme Court in Shapp omitted reference to $N L C$, the trial court had explicitly questioned the constitutionality, after $N L C$, of congressional bypass of the state legislature. $27 \mathrm{~Pa}$. Commw. Ct. 312, $325 \mathrm{n} .4$, 367 A.2d 791, $799 \mathrm{n.4}$ (1976). The dissent in the state supreme court, in contrast, dismissed NLC, saying that gubernatorial control of federal block grants by no means limits any "undoubted attribute of state sovereignty." $480 \mathrm{~Pa}$. at 478,391 A.2d at 609 (dissent). 
not based on the commerce power; ${ }^{68}$ rather, they are grounded in the spending power. ${ }^{69}$ Further, the Court in NLC expressly reserved opinion on whether congressional interference with state sovereignty would be unconstitutional if exercised through the spending, rather than the commerce, power. ${ }^{70}$ As the next section will show, courts have allowed interference with state sovereignty through the spending power even after $N L C$.

\section{B. Sovereignty and the Spending Power}

Prior to NLC, the Supreme Court consistently upheld Congress's right to impose conditions on federal grants, even if Congress accomplished a result that would be unconstitutional if achieved other than through the spending power. ${ }^{71}$ In the landmark 1937 case of Steward Machine Co. v. Davis, ${ }^{72}$ the Supreme Court said that a grant could neither "coerce" the states ${ }^{73}$ nor "call for a surrender ... of powers essential to their quasi-sovereign existence," 74 but Justice Cardozo's opinion questioned whether federal legislation that induces the states to act by promise of federal funds could ever be deemed "coercive." 75 Ten years later, in Oklahoma v. United States Civil Service Commission, ${ }^{70}$ a state challenged a federal ultimatum that it remove its highway commissioner for engaging in local political activity or give up federal highway assistance funds. Oklahoma's contention that the grant condi-

68 U.S. Const. art. I, $\$ 8$, cl. 3.

69 Id. cl. 1.

70 "We express no view as to whether different results might obtain if Congress seeks to affect integral operations of state governments by exercising authority granted it under other sections of the Constitution such as the spending power, Art. I, $\$ 8$, cl. 1, or $\$ 5$ of the Fourteenth Amendment." 426 U.S. at 852 n.17. Many commentators argue, however, that if constitutional principles of federalism outside article I protect state sovereignty, then the same principles limit all article I powers. See, e.g., Stewart, supra note 9, at 1254; New Safeguards, supra note 9, at 745; Municipal Bankruptcy, supra note 9, at 1884 .

71 In United States v. Butler, the Supreme Court adopted the view that the spending power, art. $I, \S 8, \mathrm{cl} . \mathrm{l}$, is a positive grant of power to spend. "Congress ... has a substantive power to tax and to appropriate, limited only by the requirement that it shall be exercised to provide for the general welfare of the United States." 297 U.S. 1, 65-66 (1936). Thus the Court later was able to say that although "the United States is not concerned with, and has no power to regulate, local political activities as such of state officials, it does have power to fix the terms upon which its money allotments to states shall be disbursed." Oklahoma v. United States Civil Serv. Comm'n, 330 U.S. 127, 143 (1947).

72301 U.S. 548 (1937).

73 Id. 589.

74 Id. 593.

75 Id. 589-90.

76330 U.S. 127 (1947). 
tion invaded its sovereignty was rejected because, as stated in an earlier case, "the statute imposes no obligation but simply extends an option which the State is free to accept or reject." 77 Oklahoma is the most serious obstacle to any state-protecting limitation on the spending power: if acceptance of federal funds entitles the federal government to insist that a state official be discharged, then Congress might also impose a particular governmental structure on states as a condition of receiving federal aid.

Further, the Supreme Court upheld the condition in a more recent case involving a clash between federal grant conditions and a state's constitutional spending provisions. In Wheeler v. Barrera ${ }^{78}$ Missouri argued that its constitution barred it from allocating any public funds, including its share of federal aid, to any private school, thus preventing compliance with Title I of the Elementary and Secondary Education Act of $1965^{79}$ requiring special programs for both private- and public-school students. Although the Court instructed the state agency to "accommodate" the federal conditions with the state constitution, it further suggested that if conditions continued to clash with state spending proscriptions as interpreted by the state supreme court, ${ }^{80}$ then the state either had to change its constitution or forfeit the federal grant. "[I]llegality under state law" would not be a defense to a charge of noncompliance. ${ }^{81}$

No court besides Oklahoma or Wheeler has deemed the fiscal dilemma posed by potential loss of substantial federal aid to be coercive. ${ }^{82}$ Because states are now so dependent on federal

77 Massachusetts v. Mellon, 262 U.S. 447, 480 (1923); see Oklahoma v. United States Civil Serv. Comm'n, 330 U.S. 127, 143-44 (1947).

78417 U.S. 402 (1974).

7920 U.S.C. $\$ \$ 241 \mathrm{a}-2410$ (1976).

80 The Court rejected the solution of the court of appeals, which had said that federal funds were subject only to federal laws and not affected by any state constitutional proscription. On the contrary, said the Wheeler Court, "whether federal aid is money 'donated to any state fund for public school purposes' within the meaning of the Missouri Constitution . . . is purely a question of state and not federal law." 417 U.S. at 418-19. Accordingly, were a case like Shapp to be heard on the merits by the Court, it is possible that the justices would begin their analysis by accepting the state court's determination of whether federal grants were affected by the state constitution.

81 Id. 420. The Court indicated that such an attempt at accommodation and compromise was appropriate in this case because the legislative history of the Act "evinced a clear intention that state constitutional spending proscriptions not be preempted as a condition of accepting federal funds." 'Id. 417 .

82 See L. TrRBE, supra note $64, \$ 5.10 ;$ Dam, supra note 2 , at 292-93. For example, the court in North Carolina ex rel. Morrow v. Califano, 445 F. Supp. 532 (E.D.N.C. 1977), aff'd mem., 435 U.S. 962 (1978), was unmoved by the state's prediction that it would lose $\$ 50,000,000$ because a federal grant condition conflicted with the state constitution. In County of Los Angeles v. Marshall, 442 
aid ${ }^{83}$ that federal conditions under the spending power have the same practical effect as mandatory regulations under the commerce power, many commentators argue that the "option" of Oklahoma ${ }^{84}$ is no longer realistic ${ }^{85}$ and that the $N L G$ limits on the commerce power apply equally to the spending power. ${ }^{86}$ Indeed, if ever a spending-power case presented a strong state-autonomy interest worthy of protection, Shapp $v$. Sloan would seem to be it. ${ }^{87}$ Shapp should qualify as the kind of "extreme case" expressly anticipated after NLC by at least two commentators, who recommended that courts invalidate any federal grant condition that requires "drastic or unusual restructuring of state governmental machinery" 88 or "subvert[s] the independence of state legislatures." 89

Two recent cases, however, indicate that $N L C$ has not made grant conditions subject to tenth-amendment attack, even when a federal grant seeks to dictate a certain governmental structure as a condition for receiving financial aid. Although neither case involves a state's system of checks and balances, each confronts the sovereignty issue and suggests that limits to the spending power exist only for extreme or unsual constraints on the structure of state government. $^{.0}$

F. Supp. 1186 (D.D.C. 1977), the court upheld federal grant conditions against a tenth-amendment challenge despite assertions that compliance would result in virtual bankruptcy of some cities:

The Court notes these allegations with sadness; this Court has merely done its duty to apply the law ..... The Court is confident that a concerted effort by federal executive, legislative, and state and local branches of government can and must find a solution to the social and economic problems involving the people and governmental entities which are affected directly and indirectly by the issues raised herein.

Id. 1192 n.5.

83 See notes 2 \& 30 supra and text accompanying notes 1-4 supra.

84 See note 77 supra and accompanying text.

85 See, e.g., Stewart, supra note 9, at 1254, 1262; New Safeguards, supra note 9 , at $745-46$.

86 See note 70 supra.

87 See text accompanying notes 114-32 infra.

88 "Federal funding can be withdrawn from a state program that fails to comply with federal conditions relevant to the purpose of that program, if the conditions are 'necessary and proper' to achieving the objectives of the funding and do not require drastic or unusual restructuring of state governmental machinery." Stewart, supra note 9 , at 1262 .

89 "If National League of Cities is interpreted as establishing a balancing test weighing the relative importance of the federal interest against the strength of the state's interest in autonomy, then in extreme cases the balance may swing against federal grants-in-aid that impose conditions subverting the independence of state legislatures." Dam, supra note 2, at 293-94 (footnote omitted).

90 See note 88 supra. 
In Montgomery County v. Califano, ${ }^{91}$ local officials argued that a grant program ${ }^{92}$ offended the tenth amendment by shifting control of health-care delivery from the county to agencies appointed by the governor. In barest terms, the local elected officials complained that they had been bypassed in favor of specialists, a complaint reminiscent of Shapp. The court, however, was not swayed, concluding instead that although governmental structure was changed, the grant program was constitutional because the agencies received local substantive input.

Applying the line of cases from Steward ${ }^{93}$ to North Carolina ex rel Morrow v. Califano, ${ }^{94}$ the court decided that the governmental structure dictated by the program served "a legitimate national end" and that the sanction of withholding federal funds did not "cross the line which divides inducement from coercion." 95 Satisfied that the program survived traditional spending-power analysis, the court nonetheless addressed NLC: Montgomery County was significantly different from $N L C$, it said, because the program did not "displace local initiative with federal directives." 96 The court also observed that the new agencies would be "manned by area residents, some or many of whom will be local elected officials." 97 Because of this local input, the program did not interfere with state sovereignty as prohibited by $N L C . .^{98}$

Although the court's inquiry into the amount of local input shows some concern for state sovereignty, the court showed no solicitude for the state's governmental process or structure; instead, its concern was with local substantive input. Thus, measured by the standard of Montgomery County, the mere provision for local input removes any objection that block grants might impair the "integrity of the states," 99 even if the input is structured differently from the state's chosen governmental apparatus.

91449 F. Supp. 1230 (D. Md. 1978).

92 National Health Planning and Resources Development Act, 42 U.S.C. $\$ \$ 300 \mathrm{k}-$ $300 t$ (1976).

93 Steward Mach. Co. v. Davis, 301 U.S. 548 (1937).

94445 F. Supp. 532 (E.D.N.C. 1977), aff'd mem., 435 U.S. 962 (1978).

95449 F. Supp. at 1247.

96 Id. This quotation is from the traditional spending-power analysis but is by reference incorporated in the $N L C$ argument. See $i d .1248$.

97 Id. 1247.

98 Id. 1248.

99 Id. 
In Florida Department of Health and Rehabilitative Services v. Califano, ${ }^{100}$ a state plan for reorganization of its health department conflicted with a federal grant program ${ }^{101}$ because the state divided administrative responsibility for the program instead of giving "substantial authority" to a single director. ${ }^{102}$ The court rejected Florida's argument that the program, "to the extent it conditions receipt of federal grant monies on the adoption by a state of a particular governmental structure, constitutes an invalid encroachment upon the powers ... of the states in derogation of" the tenth amendment and $N L G .{ }^{103}$

The court based its decision on a "narrow" reading of $N L G .{ }^{10 *}$ Expressing doubt that $N L G$ applies to the spending power, the court noted that insofar as the grant conditions interfered with state governmental structure, "the federal intrusion is wholly indirect." Furthermore, it said that the conditional nature of the grant program made it "purely voluntary" rather than "coercive" or "mandatory." 105

Taken together, Florida Department of Health and Montgomery County demonstrate NLC's limited impact on state-federal relations: a condition that interferes with state governmental structure is constitutional as long as local input remains and the program is voluntary. The LEAA program involved in Shapp meets these criteria. Although it interferes with the state legislature's role, it substitutes another local figure, the governor. ${ }^{106}$ The program is of the same voluntary nature as the one in Florida Department of Health. Thus, an argument that the grant conditions in Shapp are unconstitutional cannot be based on a generalized notion that a state's governmental structure is beyond the reach of Congress's spending power; rather it must rest on the particular interference by LEAA and on the special status of checks and balances.

\section{The Special Sovereignty Interest in Checks and Balances}

Before discussing whether anything about Shapp should make it an exception to the usual spending-power analysis-that is, whether the particular state governmental structure that has been

100449 F. Supp. 274 (N.D. Fla.), aff'd mem., 585 F.2d 150 (5th Cir. 1978), cert. denied, 99 S. Ct. 2051 (1979).

101 Rehabilitation Act, 29 U.S.C. $\$ \$ 701-794$ (1976).

102449 F. Supp. at 282.

103 Id. 283.

$1047 d .284$.

105 Id.

106 See text accompanying notes 17-20 supra. 
interfered with deserves special protection-it is useful to consider the special concern with protecting a state's political institutions and mechanisms for their own sake. ${ }^{107}$ In one view, such issues are unimportant because federalism itself is only marginally significant. ${ }^{108}$ Another perspective, however, emphasizes the critical role of the states in the political system: ${ }^{109}$ they prevent overdomination by a central federal regime and serve as laboratories for experimentation ${ }^{110}$ which counteract any stagnation resulting from having only a single centralized source of law. ${ }^{111}$

Vigorous state legislatures and judiciaries are crucial to performance of these functions and therefore deserve constitutional protection. ${ }^{112}$ Accordingly, federal action causing substantial atrophy of state legislatures or state political dialogue should be suspect. This argument, however, is overly broad: it would invalidate all grant conditions because they are presumably imposed to restrict action by state officials. ${ }^{113}$ Solicitude for state sovereignty interests would at first glance seem less critical in cases involving block grants such as those of LEAA, in which Congress has bowed to state interests and given local officials broad responsibility. After all, Congress could have imposed stricter grant conditions or pro-

107 A preliminary question might be why the courts, rather than members of Congress elected from the states, should resolve federalism controversies. Commentators are divided on this issue. See Choper, The Scope of National Power Vis-a-Vis the States: The Dispensability of Judicial Review, 86 YAxE L.J. 1552, 1560-63 (1977); Cohen, Congressional Power to Interpret Due Process and Equal Protection, 27 STAN. L. Rev. 603, 613-14 (1975); Stewart, supra note 9, at 1263-72; Tribe, Intergovernmental Immunities in Litigation, Taxation, and Regulation: Separation of Power Issues in Controversies About Federalism, 89 HaRv. L. Rev. 682, 712-13 (1976); Wechsler, supra note 9; Municipal Bankruptcy, supra note 9, at $1884-91$.

In any event, a footnote in $N L C$ rejects the view that Congress, not the courts, should safeguard federalism. National League of Cities v. Usery, 426 U.S. 833, 841 n.12 (1976).

108 See, e.g., Choper, supra note 107, at 1565-67, 1611-21.

109 See, e.g., Municipal Bankruptcy, supra note 9, at 1886-87.

110 "It is one of the happy incidents of the federal system that a single courageous State may, if its citizens choose, serve as a laboratory; and try novel social and economic experiments without risk to the rest of the country." New State Ice Co. v. Liebmann, 285 U.S. 262, 311 (Brandeis, J., dissenting).

111 Municipal Bankruptcy, supra note 9, at 1886-87. See also Linde, Justice Douglas on Freedom in the Welfare State-Constitutional Rights in the Public Sector, 39 WASH. L. Rev. 4, 28-31 (1964).

112 See U.S. Advisory Commission on Intergovernmental Relations, Making tree Safe Streets Act Work: An Intergovernmental Challenge, No. A-36, 15,17 (1970) [hereinafter cited as ACIR ChatLENGE].

113 This argument has also been rejected in the spending-power cases. See text accompanying notes 72-77 and 91-106 supra. 
vided for administration entirely by federal officials. ${ }^{114}$ Surely, administration by state or local officials would be preferable. ${ }^{115}$

Deeper analysis, however, suggests that a particular type of structural integrity-a state's chosen system of checks and balancesis seriously affected when Congress bypasses state legislatures and dictates that governors and state bureaucracies, together with their federal counterparts, shall decide how federal grants are spent. Although such interference with state structural integrity has rarely evoked a state-protecting response in spending-power cases, interference with checks and balances, because it converts the governor into a virtual legislator, should be constitutionally impermissible not only because it is a particularly great intrusion on a state's autonomy but also because it runs roughshod over a system of government which still substantially represents the normative sense of how intragovernmental powers ought to be organized. Indeed, letting federal agents bypass state governments altogether by dictating exactly how grants are spent disrupts state sovereignty less than giving discretion to only one branch of government at the risk of upsetting the state's internal balance of power.

A state's chosen system of separation of powers may indeed be a basic element of statehood protected by the Constitution. ${ }^{116}$ One justice has expressed great concern over the prospect of a branch of the federal government reviewing a state's governmental structure:

It would make the deepest inroads upon our federal system for this Court now to hold that it can determine the appropriate distribution of powers and their delegation within the forty-eight states. As the earlier Mr. Justice Harlan said for a unanimous Court in Dreyer $v$. Illinois, 187 U.S. 71, 84 [1902]:

"Whether the legislative, executive and judicial powers of a State shall be kept altogether distinct and separate, or whether persons or collections of persons belonging to one department may, in respect to some matters, exert powers which, strictly speaking, pertain to another department of gov-

114 Linde, supra note 111 , at 30 n.111. Some commentators say that direct federal administration of grants would be so unwieldy as to be impracticable. They conclude that Congress therefore might accept judicial limits on grant conditions rather than switch to direct federal administration. See id.; Stewart, supra note 9, at $1240-41$.

115 See text accompanying notes 96-98 supra.

116 See note 64 supra and text accompanying notes 64-66 supra. 
ernment, is for the determination of the states." 117

This view recommends itself not only because of its high regard for separation of powers, ${ }^{118}$ but also because a system of checks and balances is, by its very nature, fragile: it can easily be destroyed by federal spending. State legislators fear that as federal aid increases and accounts for a larger portion of a state's available resources, ${ }^{119}$ their importance and effectiveness will decline unless they exert some control over the expenditure of such funds: their political accountability for in-state programs would decline. Legislators contend that their "inherent right" to control state spending "is at the heart of the practical exercise of power at the state level." 120

This argument was important to the decision in Shapp, in which the court noted:

$[T]$ wenty-five percent of Pennsylvania's budget is now derived from federal funds. The logical result of appellant's argument [that the executive branch controls the funds]if the percentage were, as an example, to reach one hundred percent-would be to eliminate the need for a legislative branch of government. The federal government could simply supply federal monies to the executive branch which would then proceed to administer the revenue without appropriation of any of the monies by the legislature. ${ }^{121}$

The danger, in the court's view, was not merely hypothetical:

To hold that the Executive has control of these federal funds . . . would result in . . . obliteration of the distinctions between the separate functions and powers of these two co-equal branches of government. ... With a large portion of the state budget now provided by federal funding, the executive branch could well end up with as much legislative responsibility as the General Assembly itself.

117 Sweezy v. New Hampshire, 354 U.S. 234, 256 (1957) (Frankfurter, J., concurring in the result); cf. Mayor of Philadelphia v. Educational Equality League, 415 U.S. 605, 615 n.13 (1974) ("[T] The State of Pennsylvania may ... pattern its government after the scheme set forth in the Federal Constitution or any other way it sees fit. The Constitution does not impose on the States any particular plan for the distribution of governmental powers.") (Citation omitted).

118 See text accompanying notes 128-32 infra.

119 See text accompanying notes 1-2 supra.

120 ACIR Bunc., supra note 1, at 14 (remarks of Harold Schreier); see text accompanying note 4 supra.

$121480 \mathrm{~Pa}$. at $468,391 \mathrm{~A} .2 \mathrm{~d}$ at 604. 
It is that result which we feel would "clearly and palpably" violate the doctrine of separation of powers embodied in our Constitution. ${ }^{122}$

The delicate balance of power had already been upset. The squabble over the special prosecutor's office revealed the capacity of the executive branch to spend money despite legislative disapproval. ${ }^{123}$ The Pennsylvania legislature cited still other instances of federal grants being used by state bureaucrats to establish or perpetuate programs specifically rejected by the legislature. ${ }^{124}$ Fiscal conservatives also objected that federal monies were used as a foot in the door to start programs that the legislature would subsequently be under political pressure to continue after the federal funding ceased.

The Governor's brief responded that the LEAA grant program did not deprive the legislature of control because the lawmakers can always deny state agencies authorization to apply for federal grants in the first place.125 This "right of first refusal," however, requires the legislators to make an irrevocable commitment when plans are still embryonic, subject to modification by federal authorities, and months away from actual implementation. Thus, the legislature's ability to respond to constantly changing circumstances and needs is impaired.126 Although the legislature can theoretically withhold aggregate matching funds at a later stage, this forfeiture of federal assistance on a lump-sum basis because of a few objectionable projects within a program can be politically and economically hazardous. ${ }^{127}$ Because none of these options grants the legislature truly effective leverage and discretion in the federal funding process, it is questionable whether the balance between the legislative and executive branches is preserved.

122 Id. at $469-70,391 \mathrm{~A} .2 \mathrm{~d}$ at 605 (emphasis added).

123 See note 29 supra.

124 Brief for Appellee at 3. See also Record at 256a-63a. For instance, it said that, during two previous years, increasing concern over the size and attendant expenses of the central office staff for the state Drug Abuse Council had caused the legislators to initiate cutbacks in that agency's award of state monies in an effort to cut waste and ensure that funds for treatment of addicts would reach their intended destination, the field programs. The response of the agency was to reallocate its federal grant dollars to the central office, undermining the legislative intent. Id.

125 Brief for Appellants at 37, 41 [hereinafter cited as Governor's Brief].

126 The same objections apply to the suggestion that, at least in the case of the LEAA, the legislature can pass substantive legislation vetoing specific projects at the advisory review stage, before the state agency submits its plan to LEAA. See note 28 supra.

127 See note 29 stupra. 
By interfering with a state's chosen distribution of powers, programs such as the LEAA invade one of the basic elements of state sovereignty. Such an impact should raise tenth-amendment concerns even in a spending-power context because the existence of coequal branches of government represents the normative sense of how intragovernmental powers ought to be organized. ${ }^{128}$ Indeed, since the writing of the Constitution, the doctrine of checks and balances has been regarded as a "political maxim," basic to liberty. ${ }^{129}$ "No political truth is certainly of more intrinsic value, or is stamped with the authority of more enlightened patrons ...."130 The LEAA program does not merely upset the normative balance of power: it interferes with a power that is normatively the legislature's-the power of appropriation. ${ }^{131}$ The Shapp court reasoned:

The federal government may impose conditions and limitations upon the monies it allocates to the states and the General Assembly must stay within those guidelines or refuse the grant. Within each grant, however, there remains

128 See generally TFE FEDERALIst No. 47 (J. Madison); see also Dreyer v. Mlinois, 187 U.S. 73, 84 (1902).

129 The Federalist No. 47 (J. Madison) 336 (B. Wright ed. 1961) (Ist ed. New York 1788). (1967):

130 Id.; see M. Vire, Constrtutionalism and the Separation of Powers 1-2

[T] he doctrine of the separation of powers has, in modern times, been the most significant, both intellectually and in terms of its influence upon institutional structures. It stands alongside that other great pillar of Western political thought-the concept of representative government-as the major support for systems of government which are labelled "constitutional." ... [I]t remains, in some form or other, the most useful tool for the analysis of Western systems of government, and the most effective embodiment of the spirit which lies behind those systems.

131 One court has said:

Under all constitutional governments recognizing three distinct and independent magistracies, the control of the purse strings of government is a legislative function; indeed, it is the supreme legislative prerogative, indispensable to the independence and integrity of the legislature, and not to be surrendered or abridged, save by the constitution itself, without disturbing the balance of the system and endangering the liberties of the people. ... This supreme prerogative of the legislature, called in question by Charles I., was the issue upon which parliament went to war with the king, with the result that ultimately the absolute control of parliament over the public treasury was forever vindicated as a fundamental principle of the British Constitution. The American commonwealths have fallen heirs to this great principle, and the prerogative in question passes to their legislatures without restriction or diminution, except as provided by their constitutions, by the simple grant of legislative power.

Colbert v. State, 86 Miss. 769, 775, 39 So. 65, 66 (1905). See also, e.g., U.S. Const. art. I, $\$ 9$, cl. 7; PA. Const. art. III, $\$ 24$; text accompanying note 4 supra. 
the necessity to establish spending priorities and to allocate the available monies. This is properly a legislative function. ${ }^{132}$

To summarize this inquiry, it was first shown that the constitutional protection of state services discussed in NLG logically extends to a state's governmental structure. Although a state's structural integrity is not normally protected from exercise of the spending power, the exercise of that power in Shapp is exceptionally intrusive because it upsets the delicate balance of power existing between a state's executive and legislative branches. A state's chosen system of checks and balances should be immune from congressional interference because the existence of coequal branches contributes to the vigor of state governments and thus, indirectly, to the vitality of the federal system. Moreover, this system represents the normative view of how powers in government should be arranged.

\section{Limits to Balancing}

If congressional intrusion upon a state's system of checks and balances is deemed serious enough to merit judicial scrutiny and warrant departure from traditional spending-power analysis, $N L C{ }^{133}$ suggests that a court's next step may be to weigh the state interest against the asserted federal interests. ${ }^{134}$ Unfortunately, applying a balancing test to $S h a p p^{135}$ demonstrates the problems of this approach and may not furnish the state interest with sufficient protection.

The first step is to examine the federal interest, which is, as is often the case, efficiency. In the case of LEAA, committee reports reflect Congress's belief that gubernatorial authority would centralize state planning and speed the state-level approval of local subgrants. ${ }^{138}$ Furthermore, executive control would avoid legisla-

$132480 \mathrm{~Pa}$. at $470,391 \mathrm{~A} .2 \mathrm{~d}$ at 605.

133426 U.S. 833 (1976).

134 Although the majority opinion seemed to avoid actual balancing, judges and commentators have interpreted it as a balancing case. See, e.g., Usery v. Board of Educ., 421 F. Supp. 718, 719-20 (D. Utah 1976); New Safeguards, supra note 9, at 730-31; Comment, Emerging Concepts of Federalism: Limitation on the Spending Power and National Health Planning, 34 WAsy. \& LeE L. Rev. 1133, 1151 (1977). Indeed, the strongest argument for balancing is that one member of the five-man majority in NLC thought the Court was using some sort of balancing. See National League of Cities v. Usery, 426 U.S. 833, 856 (1976) (Blackmun, J., concurring). $135480 \mathrm{~Pa} .449$, 391 A.2d 595 (1978), appeal dismissed sub nom. Thornburgh v. Casey, 440 U.S. 942 (1979).

136 See S. Rep. No. 94-847, 94th Cong., 2d Sess. 16-17, reprinted in [1976] U.S. Code Cong. \& AD. News 5374, 5381-82; H.R. ReP. No. 94-1155, 94th Cong., $2 \mathrm{~d}$ Sess. 13; text accompanying note 25 supra. 
tive "politicization" of the program. ${ }^{137}$ A third rationale was that state legislators typically are removed from problems of urban crime and the needs of big cities. ${ }^{138}$ Finally, Congress believed gubernatorial supervision of LEAA was appropriate because "overall responsibility of law enforcement services resides with the chief executive." 139

Efficiency is certainly a legitimate concern of Congress in spending federal funds, but, whether a court were to apply a balancing or a least-restrictive-means approach, ${ }^{140}$ it would have to consider whether fuller participation in appropriations by the state legislature would be as effective as the statutory process. If not, the court would still have to decide if the marginally greater effectiveness of the congressional measure outweighed the intrusion on the state system of checks and balances.

This question requires an empirical inquiry that courts are ill-equipped to conduct. For example, governors may argue that legislative approval of each grant would destroy a state's flexibility to pursue unexpected grants, and also that the legislature's fragmented committee structure, insufficient staff, and lack of grantsmanship militate against meaningful participation in federal grant appropriations. On the other hand, legislatures have recently moved towards greater "professionalization," 141 including larger and better-trained staffs and better-paid legislators. Moreover, in big states with sizeable tax revenues, legislative staffs are responsible for year-round budgetary planning.

Other pros and cons could be cited, ${ }^{142}$ but the basic point is that the federal interests involved reflect highly pragmatic political considerations, and judges are unlikely to be able to measure these considerations and then weigh them against a state's abstract, normative interest in preserving traditional checks and balances. As one

137 See text accompanying note 25 supra.

138 ACIR Challenge, supra note 112, at 15, 17.

139 S. REP. No. 94-847, 94th Cong., 2d Sess. 16, reprinted in [1976] U.S. CoDE Cong. \& AD. NEws 5374, 5381.

140 See Municipal Bankruptcy, supra note 9, at 1890.

141 ACIR BuLL., supra note 1 , at 2.

142 For example, the contention that an executive agency could best coordinate LEAA plans and expenditures, see text accompanying note 136 supra, might be rebutted with the contention that if the legislature had more control, legislative committees could better integrate LEAA activities with state-funded plans. There is also evidence that, despite Congress's hopes, governors have exerted little supervision over LEAA planning, see note 23 supra, and that governors are as capable as legislators of politicization and other abuses. See H.R. REP. No. 92-1072, 92d Cong., $2 d$ Sess. 10-60 (1972); U.S. Advisory CoMamssion on Intergovernmental. Rejations, Safe Streets Reconsmered: The Brock Grant Experience: 19681975, No. A-55 at 60, 200-01 (1977). 
commentator has expressed it, "Comparing the utility gains from state compliance with federal programs with losses to state autonomy is like the proverbial comparison of apples and oranges." 143

This dilemma illustrates the difficulty of applying the stateprotecting doctrine of NLC by means of a balancing approach. The federal and state interests are incapable of clear balance or are incommensurable. To avoid such pitfalls, it has been suggested that $N L C$ be implemented by means of a categorical approach, which depends not on the weight of the federal interest but on its nature.144 Thus, in an "emergency," ${ }^{145}$ even a state's sovereignty interest in checks and balances would have to yield. Where, however, Congress clearly and substantially strengthens one branch of state government in the budgetary process at another's expense merely for efficiency, then the bypassed branch is entitled to constitutional protection. Nothing in this analysis prevents Congress from carrying out a program solely through federal agents; rather, all that is suggested is that when Congress employs state governmental machinery to plan and administer a program, then Congress must respect the state system of checks and balances.

This result may be the actual effect of the decision in Shapp and the Supreme Court's dismissal of the appeal. This manner of resolution, however, is unsatisfactory in light of Congress's express grant of mere advisory review and express intent that state legislatures have no power to approve or disapprove. The analysis in this part has shown how the same effect should have been achieved in a more explicit, principled fashion.

\section{REMEDIES}

The possibility remains that the argument in the preceding part against Congress's authority to alter a state's chosen system of checks and balances might be accepted by courts in a commerceclause context and yet be deemed irrelevant where, as in Shapp, the disruptive regulation is based on the spending power and con-

143 Stewart, supra note 9, at 1236 (footnote omitted). Indeed, it is unclear what percentage of a state's budget would have to be occupied by federal grants before a court would find a state's internal separation of powers impaired. The majority opinion in $N L C$ disclaimed the need for factual determinations of impact on state government: it perhaps recognized that a court would still be left wondering how to interpret the numbers. 426 U.S. at 851-52.

144 Stewart, supra note 9, at 1236.

145 Fry v. United States, 421 U.S. 542, 548 (1975), quoted in NLC, 426 U.S. at 853. The "emergency" in Fry involved a wage and price freeze. Justice Blackmun suggested that certain environmental programs might also be "emergencies." NLC, 426 U.S. at 856 (Blackmun, J., concurring). 
sists of a condition attached to a federal grant. If the spending power dictates a different result, it is because cases like Oklahoma v. United States Civil Service Commission ${ }^{146}$ and Florida Department of Health $v$. Califano ${ }^{147}$ indicate that the state's decision to accept the federal grant remains voluntary: it retains the ability to opt out.

This fact has important implications for the type of remedy a governor can expect if a court rejects the thesis of the preceding part and agrees with him that a state reappropriation statute impermissibly conflicts with a valid federal condition vesting control of federal grants in the executive branch. If the presumed voluntariness of federal spending programs is, in fact, the only factor which saves a congressional intrusion upon state separation of powers from being unconstitutional, then a legislature's lack of consent to the intrusive federal condition-as expressed in a noncomplying state statute-should render the governor ineligible to receive the affected federal funds. ${ }^{148}$

In Shapp, however, the Governor argued that a state law providing legislative control of federal aid violated the supremacy clause and was therefore void. The relief he sought was not termination of federal funding but rather injunctive and declaratory relief permitting him to carry out the LEAA plan without the legislature's approval. ${ }^{149}$ The Governor relied ${ }^{150}$ on a line of cases beginning with King $v$. Smith ${ }^{151}$ which indicate that a federal grant condition could invalidate a conflicting state law.

In King, the Supreme Court found that a state-imposed welfare restriction conflicted with a federal condition attached to welfare funds given to the state. Instead of deciding that the state was thus disqualified from receiving federal funds, the Court unanimously concluded that the state law was void. ${ }^{152}$ Various Justices have sought to clarify King, reminding their brethren that

146330 U.S. 127, 143-44 (1947).

147449 F. Supp. 274 (N.D. Fla.), aff'd mem., 585 F.2d 150 (5th Cir. 1978), cert. denied, 99 S. Ct. 2051 (1979).

148 This view is endorsed by the Solicitor General: "The executive branch of Pennsylvania cannot claim a right to receive federal money despite the legislative branch's refusal to abide by the conditions of eligibility. The whole Stateincluding the executive branch-loses its eligibility when the legislative branch refuses to cooperate." Solicitor's Brief, supra note 28, at 18-19. But see discussion of this argument in text accompanying notes 156-57 infra.

149 Governor's Brief, supra note 125, at 3-7.

150 Id. 80-84.

151392 U.S. 309 (1968).

152 Id. 333 n.34. 
the terms of a grant program are "in no way mandatory upon the states under the Supremacy Clause," ${ }^{153}$ and that the state might avoid the federal condition simply by rejecting the federal funds.

There is some suggestion that application of $\mathrm{King}$ is triggered only when a state has accepted federal funds and actually spent them in a way inconsistent with attached conditions. ${ }^{164}$ By assuming in the appeal of Shapp to the Supreme Court ${ }^{155}$ that the Pennsylvania General Assembly had not, in reappropriating federal grants, actually rerouted or diverted federal dollars but had simply allowed the money for unwanted projects to lapse and revert to LEAA, the Solicitor General in his brief distinguished King and therefore recommended dismissal of the governor's request for fiscal control of such lapsed funds. ${ }^{150}$

The governor's right to specific enforcement of a grant in the event a state legislature's reappropriation statute is struck down, however, should not turn on an imprecise factual determination of whether or not a state has yet "accepted" federal funds. Assuming one can determine the time of acceptance, it is usually possible and more consistent with spending-power principles for a court, even after such acceptance, simply to enjoin further use of the funds and

153 Townsend v. Swank, 404 U.S. 282, 292 (1971) (Burger, C.J., concurring). See also Rosado v. Wyman, 397 U.S. 397 (1970); King v. Smith, 392 U.S. 309, 335 n.3 (1968) (Douglas, J., concurring). The Court's decisions in King and Townsend to mandate state compliance with the AFDC grant conditions under the supremacy clause may be attributable to the adverse impact which terminating federal funds would have had on the welfare recipients ultimately involved in those cases. The Court may have simply been trying to avoid such risks by declaring the state law invalid. See Tomlinson \& Mashaw, The Enforcement of Federal Standards in Grant-in-Aid Programs: Suggestions for Beneficiary Involvement, 58 VA. L. REv. 600, 633 (1972).

154 See, e.g., Bacon v. Toia, 437 F. Supp. 1371, 1383-84 (S.D.N.Y. 1977), aff'd mem., 580 F.2d 1044 (2d Cir. 1978); United States v. Frazer, 317 F. Supp. 1079 (M.D. Ala. 1970).

155 Thormburgh v. Casey, 440 U.S. 942 (1979).

156 Solicitor's Brief, supra note 28, at 18, 19 n.16. Referring to Shapp v. Sloan, the Solicitor General commented:

This is not a case like King v. Smith ... or Townsend v. Swank ... in which a private person claiming entitlement under federal law establishes that a state has accepted federal funds but nonetheless is expending them in ways prohibited by substantive federal rules. In such cases courts properly may insist that the state use the monies in the way Congress directed.

Id. 19 n.16 (citations omitted). The last sentence leaves ambiguous whether the Solicitor General would have recommended giving the Governor the relief he desired if shown evidence that the Pennsylvania legislators did expend the funds intended for the special prosecutor's office. The position of this Comment is that recoupment of any misapplied funds should be the preferred remedy because it preserves the legislative branch's traditional choice either to comply with or opt out of a federal grant program. 
give the legislature a brief period either to cure the noncompliance or else forfeit the funds back to the federal government, not the governor..$^{157}$ If a governor's claim for specific performance of the grant program is ever to succeed, it should only be in those cases where he actually "stands in the shoes" of citizen-beneficiaries whom a court finds deserving of such equitable relief. ${ }^{158}$

The major point is that a governor's presence in such litigation should not, by itself, obscure or preempt traditional spendingpower analysis or convert such federal-state disputes into supremacyclause cases. Accordingly, if in the future a governor challenges a reappropriation statute in federal court and prevails, that court should give the state legislature time to reconsider and choose between curing the noncomplying appropriation statute and forfeiting the federal block grants affected. The court ought not to ignore the legislature's resistance to the federal condition merely because the governor is willing to spend the money in accordance with that condition. Because giving state governors almost exclusive jurisdiction over federal aid might be an impermissible intrusion on state sovereignty under $N L C$ and the tenth amendment but for the legislature's presumed consent, great weight must therefore be given to the legislature's objections.

\section{CONCLUSION}

Encouraged by the result in Shapp $v$. Sloan, ${ }^{159}$ a state legislature may reappropriate federal block grants in ways conflicting with federal law. If a federal agency like LEAA responds by cutting off the grants, and the legislature sues the agency to retain the funds, then the court may have to face the troublesome constitutional question that was avoided in Shapp.

Put simply, that question is: Does Congress violate the tenth amendment when it puts conditions on federal spending that upset a

157 Such a remedy was adopted by the Supreme Court in Rosado v. Wyman, 397 U.S. 397 (1970).

158 Cf. Califano v. Westcott, 99 S. Ct. 2655, 2663 (1979) (equitable considerations support correcting rather than invalidating defective welfare grants). Cases also may arise where a federal agency can show that its remedies at law, such as recoupment or termination of funds, are inadequate, as where a state legislature suddenly seeks to pull out of a half-completed federally supported construction project. The termination of Pennsylvania's Office of the Special Prosecutor on the verge of indictments, see note 36 supra, was arguably such a special case. Where LEAA had agreed to provide total federal funding for the project, a court might have been justified in sustaining the federally supported prosecutor to completion, even if state legislators had preferred to return the federal monies instead.

159480 Pa. 449, 391 A.2d 595 (1978), appeal dismissed sub nom. Thomburgh v. Casey, 440 U.S. 942 (1979). 
state's balance of powers? This Comment has shown that, under $\mathrm{Na}$ tional League of Cities $v$. Usery, ${ }^{160}$ direct interference with a state's checks and balances would raise a substantial constitutional question. Under traditional spending-power analysis, however, only extreme disruption of a state's governmental structure by grant conditions can transgress constitutional limitations. Because of the importance and delicacy of checks and balances, interference with them qualifies as such an "extreme disruption" and should be constitutionally proscribed despite the usual deference paid to federal grant conditions in spending-power cases. Furthermore, it is improper to read $N L C$ to require a rigid balancing test which would be contrary to this analysis.

Even if the congressional interference with state government is not considered so extreme as to invalidate the interfering grant condition, constitutional considerations limit the relief available to federal agencies or state governors seeking compliance with the grant. Courts should give the state legislature an opportunity either to conform to the grant condition or else to forfeit the conditioned funds altogether. Only in exceptional circumstances does equity require that federal funds be granted to a governor to spend against his legislature's will.

Woodrow Wilson once said that the relationship of federal and state governments "cannot ... be settled by the opinion of any one generation, because it is a question of growth, and every successive stage of our political and economic development gives it a new aspect, makes it a new question." 181 The growth of federal funds in state budgets and the increased gubernatorial discretion in administering these funds make the role of state legislatures in federal grant programs such "a new question."

160426 U.S. 833 (1976). (1911).

161 W. WILson, Constitutional Government in the Untted States 173 